\title{
The Biosynthesis of Protein
}

\author{
1. UPTAKE OF GLYCINE, SERINE, VALINE AND LYSINE \\ BY THE MAMMARY GLAND OF THE RABBIT
}

\author{
By P. N. CAMPBELL AND T. S. WORK \\ National Institute for Medical Research, The Ridgeway, Mill Hill, London, N.W. 7
}

(Received 10 December 1951)

Owing to the failure to detect in tissue extracts any peptides which might serve as intermediates in the synthesis of proteins from amino-acids, theories have been advanced for the synthesis of proteins in which intermediates between amino-acids and proteins are not involved. Most of these theories depend on some sort of template mechanism (see Haurowitz, 1950, for general review). However, the possibility that peptides may play a role in protein synthesis has been revived by the isolation in the past 10 years of many antibiotic peptides. Various explanations have been sought for the striking biological activity of these compounds (Hotchkiss, 1944; Work, 1949; Harris \& Work, 1950). The hypothesis that these antibiotics might act by virtue of structural similarity to intermediates in protein synthesis prompted us to seek evidence for the occurrence of peptides as intermediates in protein synthesis (Campbell \& Work, 1952).

Although the information in the literature on the biosynthesis of proteins and on the part played by peptide intermediates is decidedly conflicting, there is some evidence for the metabolic activity of peptides. Thus, although small peptides other than glutathione have not been isolated from fresh cell extracts, Borsook and his colleagues have shown that various cells contain peptide material of higher molecular weight. In a tissue homogenate, glycine and leucine are incorporated faster into this peptide than into proteins (Deasy, Borsook, Haagen-Smit, Keighley \& Lowy, 1949). Fischer (1948) also has found that tissue cultures of chicken myoblasts grow much better on a partial hydrolysate of protein than on a complete hydrolysate.

Against this evidence in favour of the utilization of peptides must be set the failure of peptides obtained by partial hydrolysis of proteins to be utilized in intravenous infusion experiments in men and in dogs. Such mixtures were less effective in maintaining nitrogen balance than a complete hydrolysate of the same protein, and most of the peptide was excreted in the urine (Christensen, 1950; Silber \& Porter, 1949).

Experiments on the turnover rate of isotopically labelled amino-acid in proteins have also been interpreted as favouring the exclusion of peptides as normal intermediates in protein synthesis. No difference has been found between the half times for the incorporation of various amino-acids into ratliver proteins, and Rittenberg (1948), in discussing this result, points out that if peptides were intermediates each amino-acid would probably have a characteristic and different half time. Muir, Neuberger \& Perrone (1951) came to the same conclusion after estimating the activity of the endgroup valine and the residual valine of haemoglobin. The results of experiments involving passive immunity in rabbits favour the view that interconversion of one protein to another can only take place after complete hydrolysis of the protein to its constituent amino-acids and not through peptide intermediates (Heidelberger, Treffers, Schoenheimer, Ratner \& Rittenberg, 1942; Rittenberg \& Shemin, 1946; Bulman \& Campbell, 1951).

If peptides were intermediates in protein synthesis we might expect to find evidence for their utilization as nutrients for micro-organisms, but synthetic peptides have been found to be inferior to, or no better than, the corresponding free aminoacids as nutrients for yeast (Danté \& Thorne, 1949). However, Barton-Wright (1951) found peptone and wort superior sources of nitrogen for yeast. Various synthetic peptides have also been tried as growth factors for bacteria. In most cases the peptide appears to undergo hydrolysis before being utilized, but in a few cases the peptide may be used without prior degradation (Ågren, 1947; Simmonds \& Fruton, 1948; Krehl \& Fruton, 1948; Simmonds \& Fruton, 1949a, $b$; Taylor, Simmonds \& Fruton, 1950; Malin, Camien \& Dunn, 1951; Nurmikko \& Virtanen, 1951; Virtanen \& Nurmikko, 1951). That partial hydrolysates of proteins have been found to have greater growth-promoting properties for bacteria than complete amino-acid mixtures (Sprince \& Woolley, 1945; Dunn \& McClure, 1950; Klungsøyr, Sirny \& Elvehjem, 1951) also supports the hypothesis that micro-organisms can utilize peptides per se. These observations, together with our own studies on antibiotic peptides (Work, 1949; Harris \& Work, 1950; Callow \& Work, 1952), suggested to us that an important factor in the utilization of peptides might be amino-acid 
sequence and that certain sequences might be characteristic for any one species. We decided, therefore, to examine the mechanism of synthesis of a particular group of proteins, the milk proteins; these are synthesized in the intact animal under conditions such that peptides produced by partial degradation of the animal's own plasma protein would have an excellent chance of being re-utilized for milk synthesis before degradation was complete.

Formation of milk protein was followed in lactating rabbits after injection of radioactive $\left[{ }^{14} \mathrm{C}\right]$ glycine, valine and lysine respectively. The radioactivity of plasma protein was compared with that of milk protein and each of the three amino-acids was re-isolated from the milk protein and its specific radioactivity determined. In another experiment, radioactive plasma $\left(\left[{ }^{14} \mathrm{C}\right]\right.$ glycine $)$ from one rabbit was injected into a second animal and the radioactivity of the milk and plasma compared after suitable intervals. It is tentatively concluded that the plasma protein may supply some peptides for milk synthesis, but that the larger proportion of the nitrogen of milk protein is derived from the free amino-acids of the blood. The data on specific radioactivities of amino-acids re-isolated from milk protein favour the idea that peptides are intermediates in protein synthesis.

A preliminary account of this work has already been published (Campbell \& Work, 1951).

\section{MATERIALS AND METHODS}

Glycine. The amino-acid was obtained from the Radiochemical Centre, Amersham, as [ $\left.\alpha^{11} \mathrm{C}\right]$ glycine.

Valine. Valine was supplied by the Radiochemical Centre as DL-valine with ${ }^{14} \mathrm{C}$ in the gem-dimethyl groups.

Lysine. DL-Lysine labelled with ${ }^{14} \mathrm{C}$ in the $\alpha$-position was kindly supplied by Dr H. R. V. Arnstein of this Institute (Arnstein, Hunter, Muir \& Neuberger, 1952).

Animals. Rabbits were used. The animals were allowed to suckle their own litter (not less than four) for 2 weeks and were during that period handled frequently so as to accustom them to being milked. They were fed ad lib. with a standard pellet diet (Diet 18, Bruce \& Parkes, 1946).

Milking. The litter was removed from the cage and the animal left undisturbed with food and water for about $5 \mathrm{hr}$. After this time an intravenous injection of 2 i.u. posterior pituitary extract (British Drug Houses, Ltd.) was given and milking was started at once, using a rubber catheter to fit over the nipple and applying an intermittent suction of 10-20 cm. mercury. When necessary, a second injection of hormone was given after half an hour. When enough milk had been obtained, the animal was returned to its litter and left with it until 5 or $6 \mathrm{hr}$. before the next milking. It was found quite practicable to replace the original litter by a second and younger litter when necessary, and in this way a rabbit could be kept in full lactation for several months.

Administration of valine. DL-Valine (11.9 mg.) containing $6 \mu \mathrm{c}$. of ${ }^{14} \mathrm{C}$ was dissolved in $4 \mathrm{ml}$. of isotonic saline. The solution was given in four equal doses by intravenous injection (ear vein) at intervals of $30 \mathrm{~min}$. Half an hour after the last injection the litter was removed from the animal and about $6 \mathrm{hr}$. after the first injection milk and blood (ear vein) samples were taken; the animal was returned to its litter and further samples of milk and blood were withdrawn at suitable intervals.

Administration of lysine. DL-Lysine (543 mg.) containing $11 \mu \mathrm{c}$. of ${ }^{14} \mathrm{C}$ was dissolved in $12 \mathrm{ml}$. of saline and the experiment carried out as described for valine.

Administration of glycine. Instead of dividing the dose, $11.2 \mathrm{mg}$. of glycine containing $295 \mu \mathrm{c}$. of ${ }^{14} \mathrm{C}$ were given as a single injection. In other respects the procedure was as for the other amino-acids except that a milk sample was collected at $6 \mathrm{hr}$. only and the animal was then killed and the whole of the blood collected.

A further experiment was made with glycine in which $1.8 \mathrm{mg}$. of glycine containing $5 \mu \mathrm{c}$. of ${ }^{14} \mathrm{C}$ were injected into a normal rabbit and blood samples were withdrawn after $4,6,8,10,16$ and $24 \mathrm{hr}$.

Separation of milk proteins. In the lysine and valine experiments, the milk protein was separated into a casein and a non-casein fraction. The casein was precipitated by addition of a mixture of $\mathrm{N}-\mathrm{HCl}$ and $\mathrm{N}$-acetic acid ( $1: 2$ by vol.) (Van Slyke \& Baker, 1918) to the milk previously diluted with 3 vol. of water. The casein separated cleanly at $\mathrm{pH} 4.6$ and was removed by centrifugation. The casein was resuspended in water, centrifuged, and the supernatant added to the non-casein fraction. The casein was then suspended in ethanol, centrifuged, filtered, washed with ether, and airdried. The $\mathrm{pH}$ of the aqueous solution containing the noncasein fraction was adjusted to 7.5. The protein was precipitated by heating to $100^{\circ}$. The precipitated protein was centrifuged, washed twice with water and then with methanol, filtered, washed with ether and dried. The radioactivity of the non-protein fraction was so low that it was not investigated.

In the glycine experiment three fractions were collected instead of two. Casein was separated as previously described, and the $\mathrm{pH}$ of the non-casein fraction was brought to 6 . An equal volume of saturated $\left(\mathrm{NH}_{4}\right)_{4} \mathrm{SO}_{4}$ solution was added; the precipitate obtained under these conditions is referred to as the 'globulin fraction' (Smith, 1946b). After removal of the globulin fraction the solution was saturated with solid $\left(\mathrm{NH}_{4}\right)_{2} \mathrm{SO}_{4}$; the precipitate obtained is referred to as the 'albumin fraction'. In each case the salt-free protein was isolated by heat precipitation. The non-protein fraction which only constituted about $3 \%$ of the $\mathrm{N}$ of the milk was not investigated.

In order to determine the distribution of protein in rabbits' milk the following method of fractionation was used. After separation of casein as usual, the supernatant was adjusted to $\mathrm{pH} 7$ and the solution saturated with $\mathrm{MgSO}_{4}$. The precipitate obtained is referred to as the 'globulin fraction'. After leaving the precipitate to stand overnight it was separated by filtration through Whatman no. 42 paper and washed with saturated $\mathrm{MgSO}_{4}$ solution. An equal volume of $20 \%(w / v)$ trichloroacetic acid was added to the filtrate and the precipitate obtained referred to as the 'albumin fraction'. The filtrate is referred to as the 'nonprotein fraction'. The casein was dissolved in dilute alkali and the globulin in water. $\mathbf{N}$ determinations (Kjeldahl) were carried out on these two fractions. The amount of albumin was estimated from the difference between the $\mathrm{N}$ content of the $\mathrm{MgSO}_{4}$ filtrate and the trichloroacetic acid filtrate. The distribution of protein in a typical sample of rabbits' milk as determined by this method is given in Table 1. 
Fractionation of blood proteins. Blood was withdrawn from the ear as required, heparinized and centrifuged. The red cells were washed twice with saline, lysed in water and the protein precipitated by heat after addition of ethanol. When the sample of blood taken was too small to allow proper fractionation of the plasma proteins, the plasma was mixed with the saline washings from the red cells and the protein was precipitated by adjusting the $\mathrm{pH}$ to $5 \cdot 0$ and heating.

When the plasma protein was fractionated, the following modification of the procedure described by Howe (1921, 1923) was adopted. The plasma was dialysed against distilled water until free from radioactive non-protein and then freeze-dried. The powder was redissolved in $0.9 \%$ $(\mathrm{w} / \mathrm{v}) \mathrm{NaCl}$, made up to the original volume $(21 \mathrm{ml}$.) and mixed with $10 \mathrm{ml}$. phosphate buffer ( $\mathrm{pH} \mathrm{7.8,0.326 \textrm {M } -}$ $\left.\mathrm{K}_{2} \mathrm{HPO}_{4}, 0.0243 \mathrm{M}-\mathrm{KH}_{2} \mathrm{PO}_{4}\right)$ and $10 \mathrm{ml}$. water. $\mathrm{Na}_{2} \mathrm{SO}_{4}$ $(21.6 \%, \mathrm{w} / \mathrm{v})(34 \mathrm{ml}$.) was added to precipitate the fibrin which was collected on the centrifuge. A further $170 \mathrm{ml}$. of $\mathrm{Na}_{2} \mathrm{SO}_{4}$ solution were added to the fibrin-free solution to precipitate the globulin. The precipitate was removed (centrifuge) and the supernatant saturated with solid $\mathrm{Na}_{2} \mathrm{SO}_{4}$ at $37^{\circ}$ to precipitate the albumin. Each protein was heat-precipitated, washed free of salts and dried with ethanol and ether.

For the quantitative estimation of amino-acids in plasma proteins the method of Popják \& McCarthy (1946), in which the globulin is precipitated with saturated $\mathrm{MgSO}_{4}$, was used.

Handling of protein samples. Proteins were weighed after drying in vacuo over $\mathrm{P}_{8} \mathrm{O}_{5}$ at room temperature. Unless otherwise stated, samples were hydrolysed in sealed tubes for $18 \mathrm{hr}$. at $105^{\circ}$ in $6 \mathrm{~N}-\mathrm{HCl}$.

Assay of radioactivity. All samples were plated on 1 or 2 sq.cm. disks and, when accurate comparison was being made between the specific activity of pure samples, counts were prolonged until the standard error of the count was less than $1.5 \%$. All assays were made with disks of infinite thickness. Since the counts with proteins were only approximate, no special drying precautions were taken during counting.

Isolation of lysine. Lysine was isolated as the copper benzylidene complex by the method of Turba (1948). The yields were not as good as those quoted by Turba; e.g. $820 \mathrm{mg}$. casein gave $55 \mathrm{mg}$. complex. As the scale was much smaller, this is not surprising. The copper complex was sus-

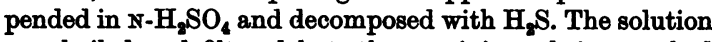
was boiled and filtered hot, the precipitate being washed with hot water. Sulphate ion was removed from the filtrate as $\mathrm{BaSO}_{4}$ and the aqueous solution of lysine concentrated until $0.5 \mathrm{ml}$. contained $15 \mathrm{mg}$. lysine. To this solution was added $1.5 \mathrm{ml}$. ethanol containing $24 \mathrm{mg}$. picric acid/ml. Lysine picrate crystallized at once. After recrystallization, this picrate was used for radioactive assay. The same weight (36 mg.) of lysine picrate from each protein was plated on a 1 sq.cm. disk before counting. To eliminate errors of area disks were then exchanged between the two samples and the mean count calculated.

Isolation of valine. After hydrolysis of the protein, the amino-acid mixture was allowed to react with excess of 1 fluoro-2:4-dinitrobenzene (FDNB) as described by Sanger (1945). The mixed dinitrophenyl- (DNP-) amino-acids were extracted into ether and the ether-soluble material fractionated on buffered Celite by the method of Perrone (1951). Preliminary separation of the mixed DNP-amino-acids from $500 \mathrm{mg}$. protein was satisfactory on a $50 \mathrm{~cm}$. column containing $60 \mathrm{~g}$. Celite 545 (Johns-Manville and Co. Ltd.,
London, S.W. 1), buffered at pH 6.6 and with ether as solvent. The DNP-valine band was, however, incompletely separated from other products and the material in it would not crystallize. The material was further purified by chromatography on a second column of $45 \mathrm{~g}$. Celite 545 (pH 6.6) using $\mathrm{CHCl}_{3}$ as solvent. The valine band $(R=0.2)$ was collected and the DNP-valine crystallized twice from ether-ligroin, m.p. $129^{\circ}$. From $480 \mathrm{mg}$. casein we obtained $29 \cdot 2 \mathrm{mg}$. DNP-valine and from $520 \mathrm{mg}$. of a mixed whey protein we isolated $16 \cdot 2 \mathrm{mg}$. DNP-valine. Before carrying out the radioactive assay of these two samples they were crystallized to constant and identical melting point, diluted, each with twice its own weight of pure synthetic DNP-Lvaline, and again crystallized.

The ease of isolation of DNP-valine is much influenced by the quality of Celite used. With two batches of Celite 545 we had no difficulty, but with a third batch we were unable to get satisfactory fractionation.

Isolation of glycine. For the isolation of glycine from casein, $200 \mathrm{mg}$. protein were used. Lactalbumin and lactoglobulin contained higher percentages of glycine than casein, and satisfactory results were obtained with $75 \mathrm{mg}$. protein. The protein was hydrolysed and treated with FDNB as before. Columns of 2.0 or $2.5 \mathrm{~cm}$. diameter were prepared with about $25 \mathrm{~g}$. Celite 545/100 mg. original protein. These columns were buffered with phosphate buffer $(975 \mathrm{ml}$. $0.25 \mathrm{~m}-\mathrm{KH}_{2} \mathrm{PO}_{4}+25 \mathrm{ml}$. $\left.0.25 \mathrm{M}-\mathrm{Na}_{2} \mathrm{HPO}_{4}\right), 16 \mathrm{ml}$. buffer being added to each $25 \mathrm{~g}$. Celite. The Celite was first sus. pended in peroxide-free ether and stirred mechanically with an efficient stirrer rotating at about $2000 \mathrm{rev} . / \mathrm{min}$. The buffer was poured slowly into this suspension and stirring continued for about $15 \mathrm{~min}$. The column was packed as described by Perrone (1951), and the ether then displaced by a $\mathrm{CHCl}_{3}-n$-butanol mixture (7 vol. $n$-butanol, 93 vol. $\mathrm{CHCl}_{3}$, saturated with water after mixing). The mixed ethersoluble DNP-amino-acids were dissolved in 10-20 ml. of this $\mathrm{CHCl}_{3}$-butanol-water mixture and transferred to the column. The glycine band $(R=0.29)$ was well separated from all other bands and was collected separately. After removal of solvent in vacuo the DNP-glycine crystallized readily, but as the quantity was less than $5 \mathrm{mg}$., crystallization was considered unsatisfactory as a method of purification. A second column of the same Celite-buffer mixture $(2 \times 16 \mathrm{~cm}$.) was used for purification of the DNP-glycine. Instead of $\mathrm{CHCl}_{3}$-butanol, washed, water-saturated, peroxide-free ether was used as solvent. The glycine band was collected in a graduated vessel and a suitable volume (about one-tenth of the whole) withdrawn for estimation of glycine. A standard curve for DNP-glycine in $0.5 \%(w / v)$ aqueous $\mathrm{NaHCO}_{3}(10 \mathrm{ml}$.) was constructed using a Hilger 'Spekker' photoelectric absorptiometer (filter 601). The curve was linear over the range $200-600 \mu \mathrm{g}$. DNP-glycine and all estimations of $\left[{ }^{14} \mathrm{C}\right]$ glycine were made within this range. For assay of radioactivity, the remaining nine-tenths of the DNP-glycine from the column was diluted with pure synthetic DNP-glycine (about $20 \mathrm{mg}$./1 mg. [14 C]DNP. glycine), the ether was removed in vacuo, and the residue crystallized from ether-ligroin. The above method of isolation was found to be more satisfactory than that described by Perrone (1951).

Isolation of serine and threonine. The mixture of DNP. amino-acids which remained on the $\mathrm{CHCl}_{3}$-butanol column after removal of DNP-glycine was washed off with acetone and the acetone solution concentrated in vacuo. The residue was dissolved by shaking with a mixture of $\mathrm{N}-\mathrm{HCl}$ and ether. 
After several successive extractions with ether, the combined ether extracts were concentrated, the residue taken up in a few drops of ethyl methyl ketone and diluted with about $10 \mathrm{ml}$. ether. A Celite 545 column (2.5 cm. diam.) was prepared with $50 \mathrm{~g}$. celite and $30 \mathrm{ml}$. buffer $/ 100 \mathrm{mg}$. original protein and with ether as solvent. The buffer ( $\mathrm{pH}$ 5.9) was a mixture of $1 \mathrm{ml}$. $0.25 \mathrm{M}-\mathrm{Na}_{2} \mathrm{HPO}_{4}$ and $9 \mathrm{ml}$. $0.25 \mathrm{M}$ $\mathrm{NaH}_{2} \mathrm{PO}_{4}$. The solution of DNP-amino-acids was transferred to the column and the chromatogram developed, first with ether and then, when a small fast band had been eluted, the ether was displaced by a mixed solvent $(150 \mathrm{ml}$. ethylmethyl ketone diluted to $500 \mathrm{ml}$. with ether and then saturated with water). After brief development with this solvent the threonine band ( $R=$ approx. 0.3 ) broke away from the main coloured zone. The threonine band was collected and DNP-threonine crystallized from etherligroin. On further development of the column a second band ( $R=$ approx. 0.15$)$ separated from the main coloured zone. This was identified as DNP-serine by comparison with synthetic DNP-serine and by alkaline hydrolysis (Lowther, 1951) to serine (identified by paper chromatography). By prolonged development of the column with the same solvent mixture, DNP-glutamic acid and DNP-aspartic acid could also be isolated.

The quantity of DNP-serine isolated was too small to permit satisfactory purification by crystallization; purification was effected by chromatography on a second Celite column $(10 \times 1.5 \mathrm{~cm}$.) using the same buffer and solvent. We satisfied ourselves by experiments with synthetic mixtures that this procedure was justified. The DNP-serine band was collected in a graduated vessel and a suitable volume (about one-twelfth) withdrawn for colorimetric assay (Spekker). A standard curve for DNP-L-serine in $0.5 \%(w / v)$ aqueous $\mathrm{NaHCO}_{3}(10 \mathrm{ml}$.) was linear over the range $150-400 \mu \mathrm{g}$. and all assays were made within this range. For assay of radioactivity the remainder of the DNP-serine was diluted with a suitable amount of synthetic DNP-L-serine and crystallized from a mixture of ethyl acetate and light petroleum (b.p. $60-80^{\circ}$ ).

Quantitative estimation of glycine. Glycine was estimated colorimetrically as DNP-glycine after separation as already described. For these quantitative estimations small Celite columns (10 x 0.7 om.) were convenient, using 3-10 mg. protein. Full details of the method are given in an Addendum to this paper.

Quantitative estimation of valine and lysine. We are indebted to Miss K. de Bouk for these estimations, which were made by the method described in a previous note (de Bouk, 1952).

\section{RESULTS}

It is not possible to obtain a continuous supply of milk from a rabbit, and the optimum time for withdrawal of our first milk sample had to be decided. Since we were interested in the possibility that blood protein was the direct precursor of milk protein, the optimum time for first milking would coincide with the maximum in the plasma radioactivity curve. [14C] glycine $(5 \mu \mathrm{c}$.) was injected into a normal rabbit and blood samples were withdrawn at intervals. The plasma protein was separated and assayed for radioactivity. It is apparent from Fig. 1 that the maximum plasma radioactivity was reached about $6 \mathrm{hr}$. after injection of $\left[{ }^{14} \mathrm{C}\right]$ glycine.

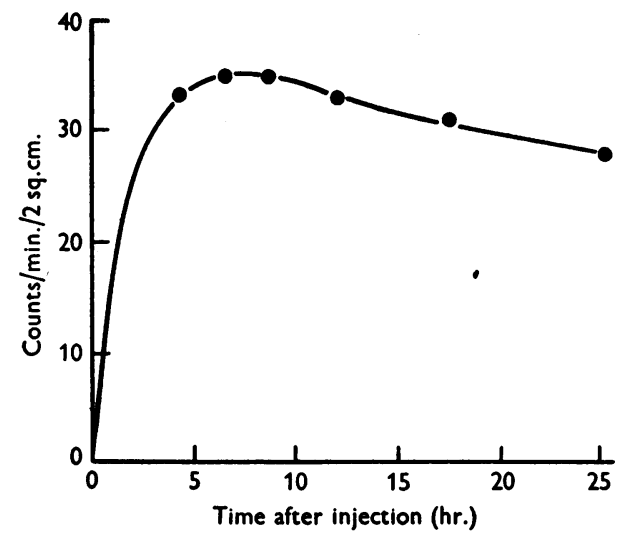

Fig. 1. Radioactivity of plasma protein from a rabbit after administration of $\left[{ }^{14} \mathrm{C}\right]$ glycine.

A lactating rabbit was injected with $295 \mu$ c. $\left[{ }^{14} \mathrm{C}\right]$ glycine and was milked $6 \mathrm{hr}$. later. When milking was completed the animal was killed and a small sample of the plasma fractionated as described under Methods. The distribution of radioactivity in blood and milk protein at this time is shown in Table 1.

Table 1. Radioactivity of blood and milk proteins (counts/min. in 1 sq.cm. sample of infinite thickness) 6-7 hr. after administration of $295 \mu \mathrm{c}$. $\left[{ }^{14} \mathrm{C}\right]$ glycine to a $3 \cdot 7 \mathrm{~kg}$. rabbit

\begin{tabular}{|c|c|c|c|}
\hline & \multicolumn{2}{|c|}{ Milk } & \multirow[b]{2}{*}{$\begin{array}{r}\text { Blood } \ddagger \\
\text { activity }\end{array}$} \\
\hline & $\begin{array}{l}\text { Weight* } \\
(\%)\end{array}$ & Activity† & \\
\hline Casein & 74 & 1222 & - \\
\hline Albumin & 13 & 1511 & 313 \\
\hline Globulin & 9 & 1378 & 776 \\
\hline Fibrin & - & - & 221 \\
\hline Haemoglobin & - & - & 68 \\
\hline
\end{tabular}

Since the picture with glycine is complicated by the rapid metabolic transformation which this amino-acid undergoes, similar experiments were made with $\left[{ }^{14} \mathrm{C}\right]$ valine and $\left[{ }^{14} \mathrm{C}\right]$ lysine. The results obtained after injection of valine are shown in Fig. 2. In this case, the animal was not killed and milk samples were collected for 7 days. The results obtained after injection of lysine are given in Fig. 3. In each case the milk proteins reached a much higher activity than the blood proteins.

Where two proteins differ in amino-acid composition it is not possible to make a direct comparison of their content of labelled amino-acid by measuring 
the radioactivity of the whole protein since this may be influenced by the amount of the relevant aminoacid in the protein. In order to check on this point, quantitative amino-acid analyses were made on

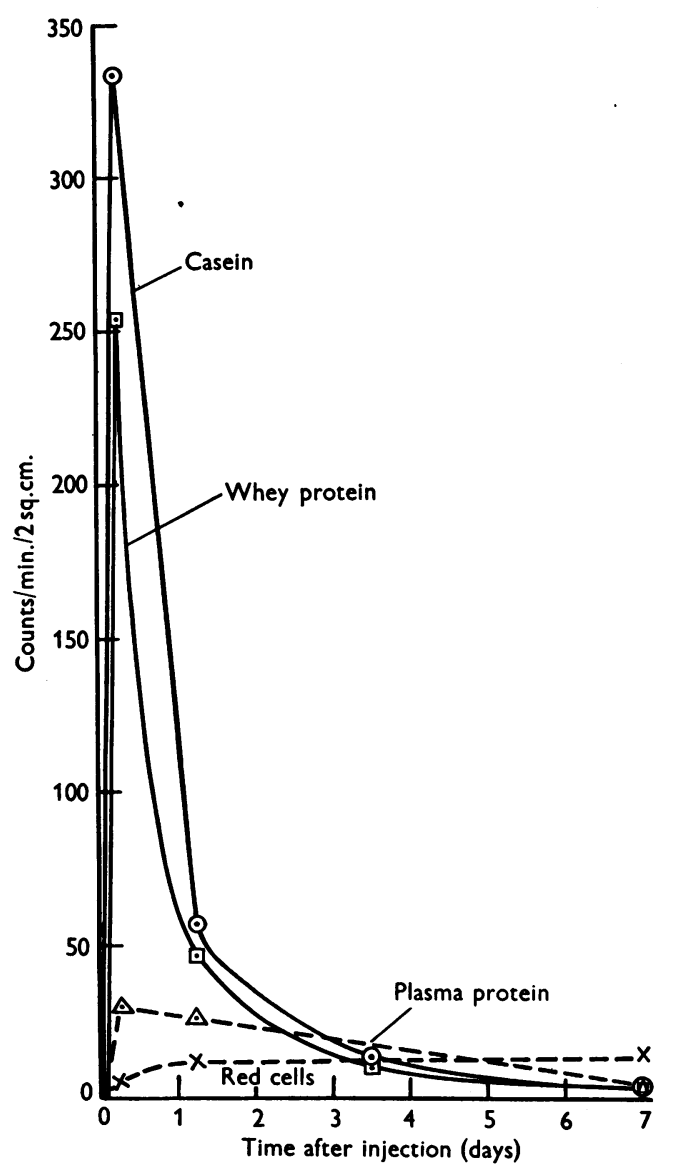

Fig. 2. Radioactivity of milk and blood proteins from a rabbit after administration of $\left[{ }^{14} \mathrm{C}\right]$ valine.

samples of rabbit plasma protein and rabbit milk proteins. The results given in Table 2 show that there are considerable differences in the amino-acid composition of plasma and milk proteins. These differences are, however, quite insufficient to explain the enormous difference in radioactivity between plasma protein and milk protein as shown in Figs. 2 and 3.

In another experiment, the radioactive carbon was injected not as free amino-acid but as labelled plasma protein. The rabbit, which had received $295 \mu$ c. ${ }^{\left.1{ }^{14} \mathrm{C}\right]}$ glycine, was killed after $7 \mathrm{hr}$., the plasma was collected, dialysed free of non-protein radioactivity, and freeze-dried. Another lactating rabbit was bled and about $25 \%$ of the blood was replaced by reconstituted radioactive plasma. Samples of blood and milk were then collected at suitable intervals and the radioactivity of the

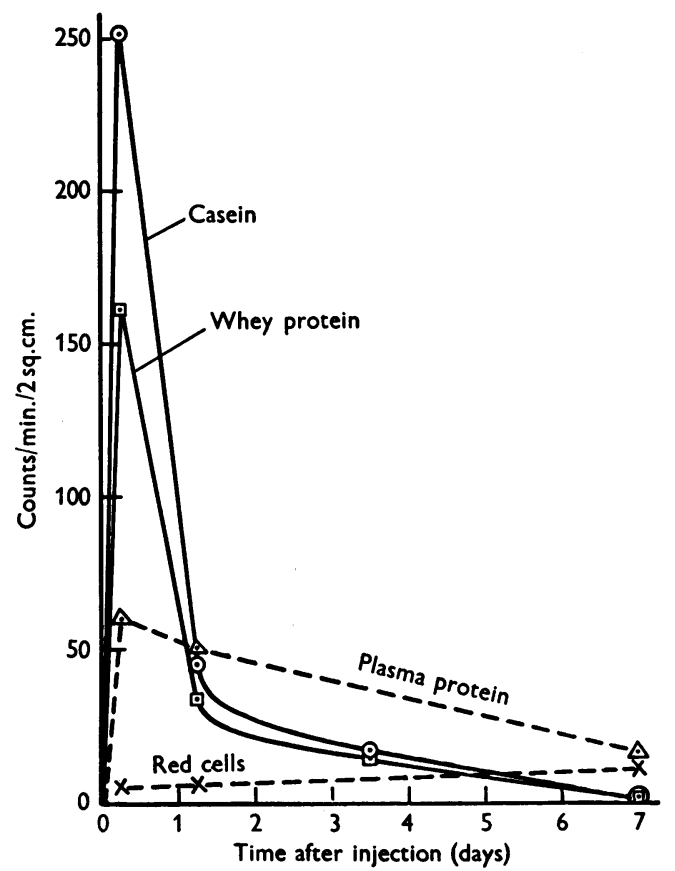

Fig. 3. Radioactivity of milk and blood proteins from a rabbit after administration of $\left[{ }^{14} \mathrm{C}\right]$ lysine.

proteins determined. Since there was sufficient radioactive plasma from the one rabbit, two parallel experiments were carried out in which two different lactating rabbits were injected with radioactive plasma. The activities of the proteins isolated in each experiment are given in Table 3. Since the

Table 2. Quantitative amino-acid analyses of various rabbit proteins

(Valine and lysine determined microbiologically, glycine colorimetrically (as DNP-amino-acid). Results expressed as g. amino-acid/100 g. protein.)

\begin{tabular}{|c|c|c|c|c|c|c|}
\hline - & r & & & & & \\
\hline & Casein & Whey protein & Albumin* & Globulin* & Albumin & Globulin \\
\hline $\begin{array}{l}\text { Valine } \\
\text { Lysine } \\
\text { Glycine }\end{array}$ & $\begin{array}{l}8 \cdot 0 \\
7 \cdot 3 \\
1 \cdot 2\end{array}$ & $\begin{array}{l}6 \cdot 4 \\
5 \cdot 3 \\
-\end{array}$ & $\overline{-}$ & $\frac{-}{3 \cdot 7}$ & $\begin{array}{l}7 \cdot 8 \\
9 \cdot 8 \\
3 \cdot 1\end{array}$ & $\begin{array}{l}9 \cdot 1 \\
6 \cdot 6 \\
2 \cdot 8\end{array}$ \\
\hline
\end{tabular}

\footnotetext{
* Fractionated with $\mathrm{MgSO}_{4}$.
} 
Table 3. Activity of milk and blood protein (counts/min. in 1 sq.cm. sample of infinite thickness) after administration of radioactive $\left(\left[{ }^{14} \mathrm{C}\right]\right.$ glycine) plasma protein to rabbits

Exp. 1

$\begin{array}{lcccccc}\text { Time after injection } & \ldots & \overbrace{1 \mathrm{hr} .} & 2 \mathrm{hr} . & 8 \mathrm{hr} . & 31 \mathrm{hr} . & 1 \text { week } \\ \text { Plasma protein } & & 79 & - & 53 & 29 & 11 \\ \text { Milk, whey protein } & & - & 0.2 & 1.5 & 2.1 & 2.1 \\ \text { Milk, casein } & & - & 0.3 & 0.8 & 1.5 & 0.7\end{array}$

$\begin{array}{ccccc}\overbrace{30 \mathrm{~min} .} & 1 \mathrm{hr} . & 6 \mathrm{hr} . & 30 \mathrm{hr} . & 1 \text { week } \\ 67 & - & 42 & 23 & 6.7 \\ \text { Z } & \text { Inactive } & 1.0 & 1.2 & 1.0 \\ 0.9 & 1.4 & 1.6 & \text { Inactive }\end{array}$

counts on the solid samples of the milk proteins were so little above background, a more sensitive method of assay was used for the milk proteins isolated in the second experiment. Mr O'Connor of this Institute kindly determined the radioactivity of the weakly active proteins by conversion of the protein carbon to carbon dioxide and assay in a sensitive gas counter. The results of these experiments are given in Fig. 4.

The results already obtained showed that there were major differences in radioactivity between plasma proteins and milk proteins, but we wished to know also whether there were differences between

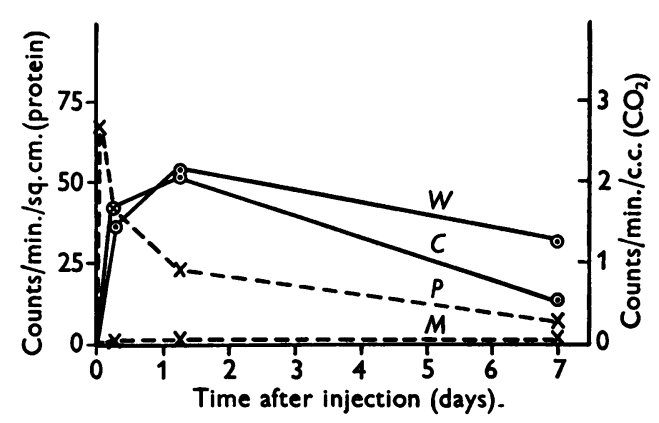

Fig. 4. Radioactivity of milk and plasma protein from a rabbit after administration of radioactive plasma protein $\left(\left[{ }^{14} \mathrm{C}\right]\right.$ glycine). Curves $W$ and $C$ : radioactivity of whey protein and casein as determined in gas counter after combustion. Curves $P$ and $M$ : radioactivity of plasma and milk protein as determined from infinite-thickness solid samples.

the milk proteins themselves and whether the injected radioactive amino-acid was in complete equilibrium or only in partial equilibrium with the amino-acids of each milk protein. To do this, it was necessary to isolate lysine, valine and glycine from the appropriate protein samples and, after purification, to determine the specific radioactivity of each amino-acid; the results are given in Table 4, the details of isolation and purification are given in the Methods section.

Provided that all the radioactivity of the milk proteins was due to the presence of the injected amino-acid, then it should be possible with the information given in Table 2 concerning the aminoacid composition of the proteins and the radioactivity of the whole protein (Table 1, Figs. 2 and 3) to calculate the specific activity of each of the injected amino-acids. A comparison of the calculated figure with that found by experiment (Table 4)

Table 4. Specific activity of pure amino-acids (counts/min. in 1 sq.cm. sample of infinite thickness) isolated from hydrolysates of milk proteins obtained $6 \mathrm{hr}$. after administration of $\left[{ }^{14} \mathrm{C}\right]$ lysine, $\left[{ }^{14} \mathrm{C}\right]$ valine, and $\left[{ }^{14} \mathrm{C}\right]$ glycine

(The values are calculated with allowance for the mol.wt. of the amino-acid derivative isolated and used for counting and for any inactive carrier used.)

\begin{tabular}{|c|c|c|c|c|}
\hline & Glycine & Serine & Valine & Lysine \\
\hline Casein & $\begin{array}{l}28000 \\
29200\end{array}$ & $\left.\begin{array}{ll}19 & 900 \\
20 & 100\end{array}\right\}$ & 3050 & 1700 \\
\hline Albumin & $\begin{array}{l}20400 \\
22600\end{array}$ & $\left.\begin{array}{ll}13 & 200 \\
13 & 050\end{array}\right\}$ & \multirow[t]{2}{*}{$2760^{*}$} & \multirow[t]{2}{*}{$1525^{*}$} \\
\hline Globulin & 25010 & 14750 & & \\
\hline
\end{tabular}

* In these cases the whey protein was treated as a single sample as the amount of milk available was considered insufficient to isolate the constituent amino-acids from the albumin and globulin fractions separately.

Table 5. Calculated and experimental values for the specific activity of amino-acids (counts/min. in 1 sq. cm. sample of infinite thickness) isolated from milk proteins $6 \mathrm{hr}$. after administration of $\left[{ }^{14} \mathrm{C}\right]$ lysine, $\left[{ }^{14} \mathrm{C}\right]$ valine and $\left[{ }^{14} \mathrm{C}\right]$ glycine

(The calculated values are $100 A / x$, where $A=$ observed activity of whole protein, and $x=\mathrm{g}$. amino-acid residue in $100 \mathrm{~g}$. protein.)

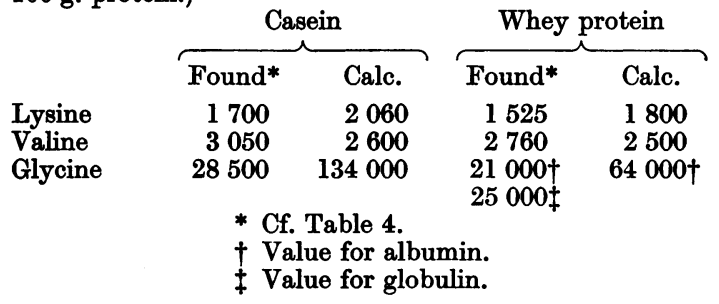

would then test the validity of the assumption. The results of such a calculation on the $6 \mathrm{hr}$. milk protein are given in Table 5 . It became obvious that, although the assumption was substantially correct for lysine and valine, it certainly was not correct for glycine. The proteins from the glycine rabbit, therefore, contained some other amino-acid which made a major contribution to the total radioactivity of the protein. Accordingly a casein hydrolysate from the $\left[{ }^{14} \mathrm{C}\right]$ glycine milk was analysed by single- 
dimensional paper chromatography. The strip was sprayed with ninhydrin in the usual way, the position of the various amino-acids marked and the strip scanned for radioactivity by an automatic recording Geiger-Muller counter. The scanning was kindly carried out for us by $\mathrm{Mr} \mathrm{D}$. O'Connor. The result (Fig. 5) left no doubt that much of the activity

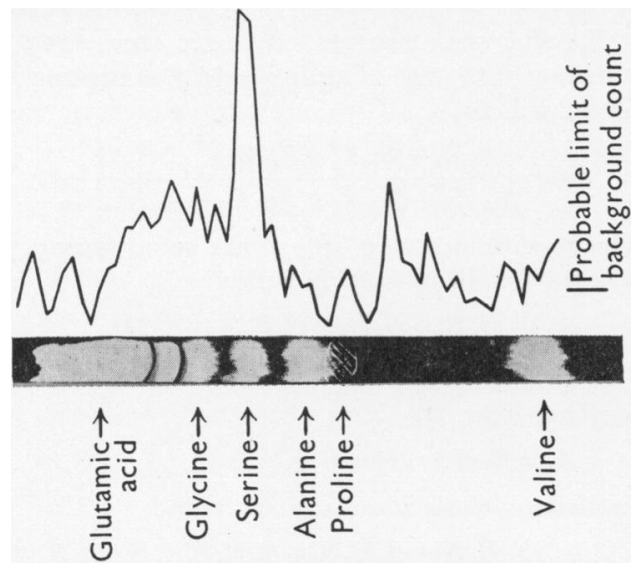

Fig. 5. Radioactivity of chromatogram of hydrolysate of casein obtained from milk of rabbit after administration of $\left[{ }^{14} \mathrm{C}\right]$ glycine. Hydrolysate chromatographed on paper in 'collidine' solvent, sprayed and coloured with ninhydrin (photograph, below), and drawn under a G.M. counter (curve, above). Owing to the monochrome of the photograph, some of the ninhydrin spots are not distinguishable. Proline is indicated by a lightly hatched area, and one spot is drawn in.

of the protein was due to serine, and accordingly a method was devised for the isolation of this amino-acid from the casein, albumin and globulin residues remaining after isolation of dinitrophenylglycine. The specific activity of the serine is recorded in Table 4.

\section{DISCUSSION}

Since the constituents of milk must be transported to the mammary gland in some form or other by the circulating blood, considerable attention has been devoted to arterio-venous changes of amino-acids and proteins in the blood of lactating goats and cows (Folley, 1949; Nikitin, 1949; Kay, 1947; Reineke, Williamson \& Turner, 1941; Graham, Peterson, Houchin \& Turner, 1937). According to Kay, 'it has been accepted for some time that the total amount of amino-acids taken up as such by the lactating gland is insufficient to account for more than a small fraction of the protein appearing in the milk'. Graham et al. (1937) suggested that a globulin fraction of the blood was utilized for milk synthesis and that part of the globulin molecule was used without prior degradation to amino-acids. On the other hand, results reported in the literature suggest that the maximum rate of synthesis of plasma protein is considerably less than would be required to supply all or nearly all the milk protein (Sprinson \& Rittenberg, 1949; Robscheit-Robbins, Miller \& Whipple, 1945). In interpreting the present results, four possibilities have to be considered: $(a)$ milk protein might be derived entirely from plasma protein by minor rearrangement of peptide chains; (b) milk protein might be derived entirely from plasma protein via free amino-acids liberated within the cells of the mammary gland; (c) milk protein might be derived partly from plasma protein and partly from blood amino-acids; $(d)$ milk protein might be derived entirely from free amino-acids without any necessity for the participation of plasma protein.

In attempting to design experiments which might help us to decide between these various possibilities, the use of radioactive isotopes appeared likely to be of great assistance. However, the high cost of radioactive amino-acids prompted us to limit the size of the animal and for this reason the rabbit was chosen. Experiments on lactating rabbits are necessarily a compromise between what is desirable and what is experimentally practicable. For example, it was found to be inadvisable to take milk and blood samples too frequently since too much disturbance of the animal interrupts milk production. The size of the protein samples was also limited so that it was not always practicable to fractionate the milk protein into albumin, globulin and casein. In these cases the milk proteins were separated into two fractions only, a casein fraction and a whey-protein fraction.

The results obtained leave no doubt that of the four possible methods for the biosynthesis of milk proteins two can be excluded. If only minor transpeptidation within pre-existing plasma protein was necessary to convert it to milk protein, then the two proteins would be expected to have approximately the same radioactivity shortly after injection of ${ }^{14} \mathrm{C}$; the activity/time curve for plasma reaches a maximum after about $6 \mathrm{hr}$. (Fig. 1) and if plasma protein were the direct precursor of milk protein, the activity/time curve for milk protein would necessarily reach its maximum some time after this and would never rise above the peak of the plasma curve (Hevesy, 1948). Reference to Fig. 2 shows that after injection of $\left[{ }^{14} \mathrm{C}\right]$ valine the casein and whey-protein activity curves reach values about ten times greater than the plasma curve. The results with lysine (Fig. 3) and glycine (Table 1) confirm the valine experiment and show that plasma protein cannot be the direct and only precursor of milk protein either by minor rearrangement of peptide chains (alternative $a$ excluded), or by prior breakdown of the plasma proteins to free amino-acids (alternative $b$ excluded).

The results obtained from the injection of labelled 
plasma protein also support the exclusion of alternatives $(a)$ and $(b)$. Thus the maximum labelling of the plasma protein in the two experiments was 79 and 67 counts/min./sq.cm. compared with a maximum activity of the milk proteins of $\mathbf{2} \cdot \mathbf{2}$ and $\mathbf{1} \cdot 6$ counts/min./ sq.cm. respectively (Table 3). It was thought that the low activity of the milk proteins might be due to the activity in the plasma being concentrated in a small fraction which was not available for milkprotein synthesis. However, the results given in Table 1 indicate that this was not so. Schoenheimer, Ratner \& Rittenberg (1942) obtained similar results after feeding amino-acids labelled with ${ }^{15} \mathrm{~N}$.

While the activity of the casein and whey-protein fractions after injection of the labelled amino-acids was far above that of the plasma it will be observed that in the case of valine and lysine the activity of the whey protein was less, and in the case of glycine more, than that of the casein. The last case is complicated by the fact that much of the glycine is rapidly converted to serine (Results and Table 4). Two explanations of these differences should be considered. First, the amount of the active aminoacid in the two proteins might be different. That this is so is shown in Table 2. Secondly, the two proteins might have been derived from amino-acid precursors of different activity. Before considering this point it is necessary to consider the effect of changes in the total rate of synthesis of milk proteins in the mammary gland on the rate of synthesis of any one of the constituent proteins.

So far as we can tell, all the milk proteins are synthesized in one type of cell (Richardson, 1947; Kay, 1947). There does not appear to be a caseinsynthesizing cell, a lactoglobulin-synthesizing cell, etc. However, the possibility must be admitted that for the purposes of protein synthesis different parts of the same cell may have different functions. There is at present no evidence on this point and in our argument it will be assumed that the cell can be considered as a whole. In any brief period (a few hours) the rate of synthesis of each of the milk proteins is likely to bear a constant ratio to the overall rate even if this varies appreciably; thus, if $R_{1}, R_{2}, R_{3}$, etc., are the rates of synthesis of whole milk protein during successive intervals of time $T_{1}$, $T_{2}, T_{3}$, etc., and $A_{1}, A_{2}, A_{3}$ the rates of synthesis of an individual milk protein $A$, then

$$
\frac{A_{1}}{R_{1}}=\frac{A_{2}}{R_{2}}=\frac{A_{3}}{R_{3}}=k_{1} \text {. }
$$

If $B_{1}, B_{2}, B_{3}$, etc., are the rates of synthesis of a second protein $B$, then

$$
\begin{gathered}
\frac{B_{1}}{R_{1}}=\frac{B_{2}}{R_{2}}=\frac{B_{3}}{R_{3}}=k_{2}, \\
\text { i.e. } \quad \frac{A_{1}}{B_{1}}=\frac{A_{2}}{B_{2}}=\frac{A_{3}}{B_{3}}=\frac{k_{1}}{k_{2}}=K .
\end{gathered}
$$

If at time $T_{0}$ we inject any suitable quantity of a radioactive amino-acid, then the concentration of this $\left[{ }^{14} \mathrm{C}\right]$ amino-acid available for protein synthesis during times $T_{1}, T_{2}, T_{3}$, etc., can be expressed as $S_{1}, S_{2}, S_{3}$, etc. The same amino-acid will also be available in the ${ }^{12} \mathrm{C}$ form in variable concentration expressed as $M_{1}, M_{2}, M_{3}$, etc.

If the rates of synthesis of milk protein $A$ at times $T_{1}, T_{2}, T_{3}$, etc., are $A_{1}, A_{2}, A_{3}$, etc., then the specific activity $(S p)$ of amino-acid $S$ in protein $A$ at time $T_{n}$ will be

$$
S p=\frac{S_{1} A_{1}+S_{2} A_{2}+S_{3} A_{3}+\ldots S_{n} A_{n}}{M_{1} A_{1}+M_{2} A_{2}+M_{3} A_{3}+\ldots M_{n} A_{n}} .
$$

The specific activity $(S q)$ of the same amino-acid in a second milk protein $B$ will be

$$
S q=\frac{S_{1} B_{1}+S_{2} B_{2}+S_{3} B_{3}+\ldots S_{n} B_{n}}{M_{1} B_{1}+M_{2} B_{2}+M_{3} B_{3}+\ldots M_{n} B_{n}} .
$$

Rewriting Eqn. (1)

$$
A_{1}=B_{1} K, \quad A_{2}=B_{2} K, \quad \ldots, \quad A_{n}=B_{n} K .
$$

Substituting these values in (2)

$$
S p=\frac{S_{1} B_{1} K+S_{2} B_{2} K+S_{3} B_{3} K \ldots S_{n} B_{n} K}{M_{1} B_{1} K+M_{2} B_{2} K+M_{3} B_{3} K \ldots M_{n} B_{n} K} .
$$

Eliminating $K$ from (4), $S p=S q$ (see (3)).

Thus, even though the overall rate of milk synthesis during the $6 \mathrm{hr}$. period between injection and milking may vary, the specific activity of the injected amino-acid re-isolated from any two milk proteins should be the same.

We are, of course, neglecting in this argument any breakdown of milk protein, but as the mammary gland is a secretory organ with a high overall output such breakdown can probably be neglected over a period of a few hours. We are also assuming that the amount of amino-acid given by intravenous injection was not sufficient to cause gross changes in metabolism. In the case of valine only $12 \mathrm{mg}$. of valine was given over a period of $1.5 \mathrm{hr}$. which would not be expected to be sufficient to cause such changes. In the case of lysine, much more was given (543 mg.) over a similar period, but since substantially the same results were obtained with lysine as with valine it may be assumed that such a large dose did not affect the metabolism significantly. In the case of glycine only a small amount ( $11 \mathrm{mg}$.) was injected.

If the theoretical treatment of the specific activities is accepted, we should expect to find after injection of lysine, valine, or glycine, that the specific activity of the relevant amino-acid isolated from casein and from whey protein should be equal. Reference to Table 4 shows that the valine reisolated from the $6 \mathrm{hr}$. casein samples had a slightly higher specific activity than the valine from the whey protein. Similarly, the lysine from casein had 
a slightly higher specific activity than the lysine from whey protein. In each case the difference is rather small but is probably outside the experimental error; we would hesitate, however, to base any theory on these results alone. After injection of $\left[{ }^{14} \mathrm{C}\right]$ glycine we re-isolated not only glycine but also serine. Conversion of glycine to serine must take place before protein synthesis so that the net result is equivalent to the injection of two amino-acids simultaneously into the same animal. If we take the casein specific activity figure for each amino-acid as 100 then albumin-glycine $=75$, albumin-serine $=65$, globulin-glycin $\Theta=87$, globulin-serine $=73$. These differences are well outside the experimental error observed in successive determinations on the same sample (Table 4), and we must, therefore, seek some explanation for them.

We have assumed in our argument that the precursor of milk protein is free amino-acid and that injected radioactive amino-acid will equilibrate with this. However, the specific-activity figures indicate that the amino-acids of milk albumin and globulin were incompletely equilibrated with injected amino-acid, i.e. there must be at least two forms of lysine, valine, glycine or serine used for milk synthesis, one form being, in each case, unable to equilibrate with injected radioactive amino-acid. This 'bound' amino-acid could be represented by either protein or peptide. If we assume that the casein was synthesized entirely from free aminoacid then the amount of bound amino-acid utilized for the synthesis of the whey proteins can be calculated from the differences in the specific activities of the casein and whey-protein amino-acids. If the bound glycine was not radioactive then $25 \%$ of the albumin-glycine and $12 \%$ of the globulin-glycine must have been transferred in this form. However, since the plasma proteins were themselves labelled, the bound glycine would probably have some activity; thus our figures must represent the minimum of each amino-acid supplied in a bound form.

In attempting to decide whether the bound amino-acid is transferred as whole protein or as peptide, the evidence for the transfer of whole protein across membranes must be considered.

It has been shown that young calves absorb into the blood stream immune globulin present in colostrum (Jameson, Alvarez-Tostado \& Sortor, 1942; Marrack, 1947; Smith \& Holm, 1948), but there is no evidence for the absorption of casein from a similar source. Thus, protein which is homologous, or nearly so, probably can be absorbed from the alimentary tract, but foreign protein such as casein cannot. Dent \& Schilling (1947) also came to a similar conclusion from experiments of a different kind in dogs.

If the mammary gland possessed the same type of

Biochem. 1952, 52 permeability to proteins as the intestine, then some albumin might be transferred from the serum (Polis, Schmukler \& Custer, 1950; Coulson \& Stevens, 1950) together with some immune globulin (Smith, $1946 a, b)$. Together these proteins account for about $5 \%$ of the nitrogen of milk. Thus it is not impossible on present evidence that the bound amino-acid is in the form of protein. However, the results obtained after the injection of labelled plasma protein suggest that the 'bound amino-acid' may be in the form of peptide rather than whole protein. In this experiment the activity of the milk protein was very small compared with that of the plasma protein (Table 3). The low activity of the milk protein could have arisen by a transfer of the $\left[{ }^{14} \mathrm{C}\right]$ glycine and $\left[{ }^{14} \mathrm{C}\right]$ serine as protein, peptide, or free amino-acid. If the transfer took place as protein then the activity of the casein would be expected to be much less than that of the whey protein. However, reference to Fig. 4 shows that the activities of the two proteins up to $30 \mathrm{hr}$. after injection were very similar.

There is at present no direct evidence in support of the theory that the 'bound amino-acid' is transferred as a peptide. However, proteolytic enzymes can catalyse transpeptidation reactions in vitro (Bergmann \& Fraenkel-Conrat, 1937; Bergmann \& Fruton, 1944 ; Johnston, Mycek \& Fruton, 1950 a, $b$; Fruton, 1950; Hanes, Hird \& Isherwood, 1950, 1952 ; Waley \& Watson, 1951 ; Fruton, Johnston \& Fried, 1951), and a transpeptidase is known to exist in the mammary gland of a lactating cow (Morton, 1950). It is therefore quite reasonable to suppose that protein synthesis in the mammary gland involves simultaneous utilization of free amino-acids from the blood stream and peptides derived directly or indirectly from blood protein by such transpeptidation reactions. While this work was in progress, Anfinsen \& Steinberg (1951) published some observations on the uptake of ${ }^{14} \mathrm{CO}_{2}$ in the biosynthesis of ovalbumin. Their results also suggest that protein synthesis may take place by way of peptide intermediates.

Emphasis must be placed on the qualitative nature of the present investigation and on its exploratory character. The terms 'albumin' and 'globulin' refer in this work to protein fractions obtained at half and full saturation with ammonium sulphate, and the casein fraction is the mixed protein precipitated at $\mathrm{pH} \mathrm{4.7.} \mathrm{It} \mathrm{is} \mathrm{thus} \mathrm{possible}$ that within these groups there may be some protein formed entirely from peptides and other formed entirely from amino-acids. We hope to clarify the situation by extension of this type of investigation using a larger animal and by carrying out systematic fractionation of the proteins.

One other point emerges from the present work, the great rapidity of the transformation of glycine into serine (Elliott \& Neuberger, 1950). After 
injection of $\left.{ }^{14} \mathrm{C}\right]$ glycine, utilization of this glycine for milk synthesis will commence at once so that the glycine in the milk would be expected to have considerably greater specific activity than serine. We have not yet been able to degrade the DNP-serine obtained from milk to find whether one or two of the carbon atoms are labelled, but if we assume that only one is labelled then the specific activity of this carbon atom can be calculated. Such a calculation made with the figures from Table 4 showed that serine carbon and glycine carbon were of practically the same specific activity. This result certainly suggests that the transformation of glycine into serine is very rapid and that it may be erroneous to talk of a 'glycine pool'.

\section{SUMMARY}

1. Valine, lysine and glycine, each labelled with ${ }^{14} \mathrm{C}$, have been used to investigate the in vivo synthesis of milk proteins in the rabbit.
2. It has been shown from the activity/time curves for the milk and plasma proteins that under the conditions of these experiments the blood amino-acids contribute most of the nitrogen for the synthesis of the milk proteins.

3. A comparison of the specific activities of the labelled amino-acids isolated from the radioactive milk proteins indicates that there exist at least two forms of precursors contributing amino-acid residues for the formation of milk protein.

4. Injection of plasma protein labelled with $\left[{ }^{14} \mathrm{C}\right]$ glycine and $\left[{ }^{14} \mathrm{C}\right]$ serine resulted in only a very slight activity in the milk proteins.

5. A method for the quantitative estimation of glycine in protein by means of its dinitrophenyl derivative is described in an Addendum to this paper.

The technical assistance of Mr S. Krol throughout the course of this work is acknowledged with pleasure.

\section{REFERENCES}

Ågren, G. (1947). Acta physiol. scand. 13, 347.

Anfinsen, C. B. \& Steinberg, D. (1951). J. biol. Chem. 189, 739.

Arnstein, H. R. V., Hunter, G. D., Muir, H. \& Neuberger, A. (1952). J. chem. Soc. p. 1329.

Barton-Wright, E. C. (1951). J. Inst. Brew. 57, 415.

Bergmann, M. \& Fraenkel-Conrat, H. (1937). J. biol. Chem. 119, 707.

Bergmann, M. \& Fruton, J. S. (1944). Ann. N.Y. Acad. Sci. 45, 409.

Bouk, K. de (1952). Biochem. J. 51, 567.

Bruce, H. M. \& Parkes, A. S. (1946). J. Hyg., Camb., 44, 501.

Bulman, N. \& Campbell, D. H. (1951). Fed. Proc. 10, 404.

Callow, R. K. \& Work, T. S. (1952). Biochem. J. 51, 558.

Campbell, P. N. \& Work, T. S. (1951). Biochem. J. 49, xlvi. Campbell, P. N. \& Work, T. S. (1952). Biochem. J. 50, 449. Christensen, H. N. (1950). J. Nutrit. 42, 189.

Coulson, E. J. \& Stevens, H. (1950). J. biol. Chem. 187, 355.

Danté, W. R. \& Thorne, R. S. W. (1949). J. Inst. Brew. 55, 13.

Deasy, C. L., Borsook, H., Haagen-Smit, A. J., Keighley, G. \& Lowy, P. H. (1949). Fed. Proc. 8, 194.

Dent, C. E. \& Schilling, J. A. (1949). Biochem. J. 44, 318.

Dunn, M. S. \& MoClure, L. E. (1950). J. biol. Chem. 184, 223.

Elliott, D. F. \& Neuberger, A. (1950). Biochem. J. 46, 207.

Fischer, A. (1948). Biochem. J. 43, 491.

Folley, S. J. (1949). Biol. Rev. 24, 316.

Fruton, J. S. (1950). Yale J. Biol. Med. 22, 263.

Fruton, J. S., Johnston, R. B. \& Fried, M. (1951). J. biol. Chem. 190, 39.

Graham, W. R., jun., Peterson, V. E., Houchin, O. B. \& Turner, C. W. (1937). J. biol. Chem. 122, 275.

Hanes, C. S., Hird, F. J. R. \& Isherwood, F. A. (1950). Nature, Lond., 168, 288.

Hanes, C. S., Hird, F. J. R. \& Isherwood, F. A. (1952). Biochem. J. 51, 25.
Harris, J. I. \& Work, T. S. (1950). Biochem. J. 46, 582.

Haurowitz, F. (1950). Chemistry and Biology of Proteins. New York: Academic Press.

Heidelberger, M., Treffers, H. P., Schoenheimer, R. Ratner, S. \& Rittenberg, D. (1942). J. biol. Chem. 144, 555.

Hevesy, G. (1948). Radioactive Indicators. New York: Interscience Publ. Inc.

Hotchkiss, R. D. (1944). Advanc. Enzymol. 4, 153.

Howe, P. E. (1921). J. biol. Chem. 49, 93.

Howe, P. E. (1923). J. biol. Chem. 57, 235.

Jameson, E., Alvarez-Tostado, C. \& Sortor, H. H. (1942). Proc. Soc. exp. Biol., N.Y., 51, 163.

Johnston, R. B., Mycek, M. J. \& Fruton, J. S. (1950a). J. biol. Chem. 185, 629.

Johnston, R. B., Mycek, M. J. \& Fruton, J. S. (1950b). J. biol. Chem. 187, 205.

Kay, H. D. (1947). Brit. med. Bull. 5, 149.

Klungsøyr, M., Sirny, R. J. \& Elvehjem, C. A. (1951). J. biol. Chem. 189, 557.

Krehl, W. A. \& Fruton, J. S. (1948). J. biol. Chem. 173, 479.

Lowther, A. G. (1951). Nature, Lond., 167, 767.

Malin, R. B., Camien, M. N. \& Dunn, M. S. (1951). Arch. Biochem. 32, 106.

Marrack, J. R. (1947). Brit. med. Bull. 5, 187.

Morton, R. K. (1950). Nature, Lond., 166, 1092.

Muir, H. M., Neuberger, A. \& Perrone, J. C. (1951). Biochem. $J .49,1 v$.

Nikitin, V. N. (1949). Biokhimiya, 14, 211.

Nurmikko, V. \& Virtanen, A. I. (1951). Acta chem. scand. 5, 97.

Perrone, J. C. (1951). Nature, Lond., 167, 513.

Polis, B. D., Schmukler, H. W. \& Custer, J. H. (1950). J. biol. Chem. 187, 349.

Popják, G. \& MoCarthy, E. F. (1946). Biochem. J. 40, 789.

Reineke, E. P., Williamson, M. B. \& Turner, C. W. (1941). J. biol. Chem. 138, 83.

Richardson, K. C. (1947). Brit. med. Bull. 5, 123. 
Rittenberg, D. (1948). Cold Spr. Harb. Symp. quant. Biol. 13, 173.

Rittenberg, D. \& Shemin, D. (1946). Annu. Rev. Biochem. 15, 247.

Robscheit-Robbins, F. S., Miller, L. L. \& Whipple, G. H. (1945). J. exp. Med. 82, 311.

Sanger, F. (1945). Biochem. J. 39, 507.

Schoenheimer, R., Ratner, S. \& Rittenberg, D. (1942). J. biol. Chem. 144, 541.

Silber, R. H. \& Porter, C. C. (1949). J. Nutrit. 38, 155.

Simmonds, S. \& Fruton, J. S. (1948). J. biol. Chem. 174, 705.

Simmonds, S. \& Fruton, J. S. (1949a). Science, 109, 561.

Simmonds, S. \& Fruton, J. S. (1949b). J. biol. Chem. 180, 635.

Smith, E. L. (1946a). J. biol. Chem. 164, 345.
Smith, E. L. (1946b). J. biol. Chem. 165, 665.

Smith, E. L. \& Holm, A. (1948). J. biol. Chem. 175, 349.

Sprince, H. \& Woolley, D. W. (1945). J. Amer. chem. Soc. 67, 1734.

Sprinson, D. B. \& Rittenberg, D. (1949). J. biol. Chem. 180, 715.

Taylor, S. P., jun., Simmonds, S. \& Fruton, J. S. (1950). J. biol. Chem. 187, 613.

Turba, F. (1948). Hoppe-Seyl. Z. 283, 19.

Van Slyke, L. L. \& Baker, J. C. (1918). J. biol. Chem. 35 , 127.

Virtanen, A. I. \& Nurmikko, V. (1951). Acta chem. scand. 5, 681.

Waley, S. G. \& Watson, J. (1951). Nature, Lond., 167, 360.

Work, T. S. (1949). Proc. roy. Soc. B, 136, 159.

\title{
ADDENDUM
}

\section{The Quantitative Estimation of Glycine in Small Samples of Proteins}

\author{
Bx S. KROL \\ National Institute for Medical Research, The Ridgeway, Mill Hill, London, N.W. 7
}

While the methods developed by Stein \& Moore (1948) and Moore \& Stein $(1949,1951)$ for the quantitative determination of amino-acids using starch and cation-exchange resin give excellent results, they are time-consuming and inconvenient if only a single amino-acid is to be estimated.

The present method is a simple adaptation of the method of Sanger (1945) for the detection of 'end groups' of proteins as $N$-2:4-dinitrophenyl-(DNP-) amino-acids. It has been found to be rapid and convenient and to give results which do not vary by more than $\pm 2.5 \%$ in successive determinations. Each analysis is carried out in triplicate on 5-15 mg. protein (according to the glycine content), and several protein analyses can readily be carried through together in 2 working days. The method is both more rapid and more accurate than that described by Callow \& Work (1952).

The protein sample is hydrolysed and the resultant amino-acid mixture is allowed to react with excess 1-fluoro-2:4-dinitrobenzene (FDNB). The mixed DNP-amino-acids are dissolved in a suitable organic solvent and the DNP-glycine separated on a buffered Celite column similar to that used by Perrone (1951). The glycine is then estimated colorimetrically as DNP-glycine.

The rate of reaction of FDNB with glycine was studied and the optimum conditions for carrying out the reaction determined. The method has been applied to the estimation of glycine in the milk and plasma proteins of the rabbit.

\section{EXPERIMENTAL}

Solvents. B.P. ether was washed once with an equal volume of fresh aqueous solution of $\mathrm{FeSO}_{4}(5 \%, w / v)$ and six times with equal volumes of water. $\mathrm{CHCl}_{3}$ was washed with six changes of water, distilled and rewashed with one volume of water. $n$-Butanol was freshly distilled and the fraction boiling at $117 \pm 1^{\circ}$ used. For chromatography, a mixture of $\mathrm{CHCl}_{3}$ and butanol (93:7 by vol.) was saturated with water; this mixture is referred to throughout as $\mathrm{CB}$.

Columns. Celite 545 (Johns-Manville Co. Ltd., London, S.W. 1) (30 g.) was suspended in washed ether and $18 \mathrm{ml}$. buffer added $\left(0.25 \mathrm{M}-\mathrm{KH}_{2} \mathrm{PO}_{4} \quad 97.5\right.$ vol. $+0.25 \mathrm{M}-\mathrm{Na}_{2} \mathrm{HPO}$ 2.5 vol.). The suspension was stirred at high speed for $30 \mathrm{~min}$. A glass tube $(1.0 \mathrm{~cm}$. internal diam.) was packed to a height of $15 \mathrm{~cm}$. with the Celite mixture using the tool of Howard \& Martin (1950). The ether was allowed to drain until the top of the Celite was almost exposed and the column then washed with CB (10 ml.).

Procedure. The solution, containing 120-500 $\mu$ g. DNP. glycine, was taken to dryness over $\mathrm{P}_{2} \mathrm{O}_{5}$ in a vacuum desiccator, dissolved in 1-2 ml. CB and transferred quantitatively to a Celite column. The chromatogram was developed with CB. The glycine band $(R=0 \cdot 29)$ was sharply defined and no effluent was collected until this band was $0.5 \mathrm{~cm}$. from the bottom end of the column. The effluent was now run into a $50 \mathrm{ml}$. graduated cylinder. The glycine band left the column with the next 5-10 ml. CB, but collection was continued until the volume of CB effluent in the cylinder was $48-49 \mathrm{ml}$. The volume of CB was adjusted to $50 \mathrm{ml}$. and exactly $10 \mathrm{ml}$. $0.5 \%(w / v)$ aqueous $\mathrm{NaHCO}_{8}$ added. On shaking the stoppered cylinder, all the colour was transferred to the aqueous layer, which was separated and centrifuged to eliminate any cloudiness caused by organic solvent. The colour intensity of the DNP-glycine in the aqueous phase was measured in a 'Spekker' photoelectric absorptiometer using a violet (601) filter.

Standard curves. In order to determine the loss of DNP. glycine on the Celite column and to check that the loss was constant over the critical range of concentrations, two standard curves were prepared. Samples of a standard solution of DNP-glycine containing $60,120,300,500$ and $700 \mu \mathrm{g}$. DNP-glycine were analysed by the above procedure, each analysis being made in triplicate. There was a linear 
relationship between concentration and colour density over the range 120-500 $\mu$ g. DNP-glycine (curve $A$, Fig. 1). A second curve was prepared with another set of samples submitted to the complete procedure except for passage through Celite. Over the range 120-500 $\mu \mathrm{g}$. DNP-glycine the second curve (curve $B$, Fig. 1) was exactly parallel to the first, i.e. the loss was constant over the critical range. Curve $A$ was used in all subsequent estimations.

Reaction of FDNB and glycine. Preliminary experiments showed that reaction between FDNB and glycine in aqueous $\mathrm{NaHCO}_{3}$ was slow and a time/reaction curve was accordingly determined. Glycine (38.4 mg.) and L-glutamic

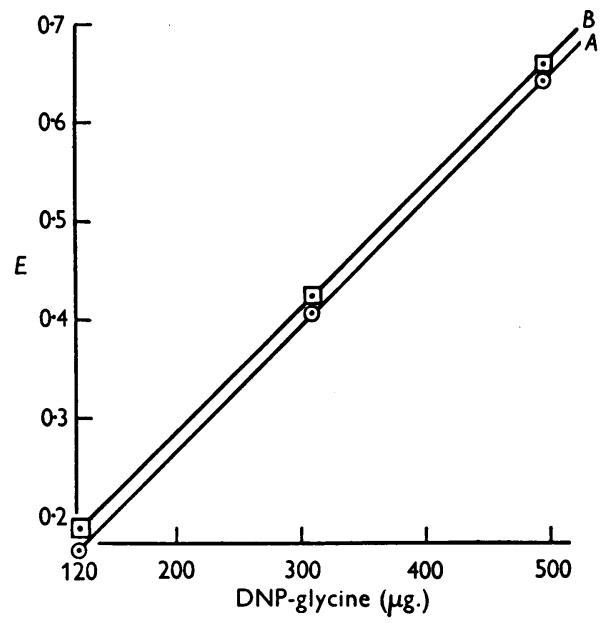

Fig. 1. Relationship between concentration and colour density of DNP-glycine. $\square-\square$, before passage of DNPglycine through column. $\odot-\odot$, after passage of DNPglycine through column.

acid (192.0 mg.) were dissolved together in water and the volume adjusted to $50 \mathrm{ml}$. Portions of this solution $(0 \cdot 2 \mathrm{ml}$.) were mixed with a $10 \%(\mathrm{w} / \mathrm{v})$ solution of FDNB in methanol $\left(0.2 \mathrm{ml}\right.$.) and $6 \mathrm{mg}$. $\mathrm{NaHCO}_{3}$ added. Samples were shaken in $6 \times 0.5$ in. test tubes for 12 and $30 \mathrm{~min} ., 1,2$ and $4 \mathrm{hr}$. At the appropriate time, each sample was diluted with water ( $1 \mathrm{ml}$.) followed by peroxide-free ether $(5 \mathrm{ml}$.). The solutions were mixed and the ether layer transferred to a clean tube with the aid of a bulb pipette and a rubber teat. The ether was washed with three lots of $1 \mathrm{ml}$. water, the washings being added to the main aqueous fraction. This fraction was acidified with $3 \mathrm{~N}-\mathrm{HCl}(0.5 \mathrm{ml}$.) and extracted with eight lots of $5 \mathrm{ml}$. ether. The combined ether extracts were evaporated to dryness in vacuo without raising the temperature and the residues dried rapidly in a vacuum desiccator over $\mathrm{P}_{\mathbf{g}} \mathrm{O}_{5}$. Each sample was finally dissolved in 1-2 ml. CB and analysed by the standard procedure. Colour density was plotted against time (Fig. 2). It is apparent from Fig. 2 that reaction was complete in about $4 \mathrm{hr}$. and this was adopted as the standard time. In order to check that the result was independent of the concentration of glycine, a second series of experiments was made using a smaller quantity of glycine $(50 \mu \mathrm{g}$.$) in a larger volume of reaction mixture (0.5 \mathrm{ml}$. water, $0.5 \mathrm{ml}$. of $10 \%$ methanolic $\mathrm{FDNB}, 10 \mathrm{mg} . \mathrm{NaHCO}_{3}$ ). Reaction was complete ( $102 \%$ recovery) in $4 \mathrm{hr}$.

Estimation of glycine in proteins. A typical analysis is reported below. Other results are given in the paper of Campbell \& Work herewith (Table 2).

Rabbit milk albumin (7.5 mg.) was hydrolysed for $16 \mathrm{hr}$. at $105^{\circ}$ in a sealed evacuated tube with about $0.05 \mathrm{ml}$.

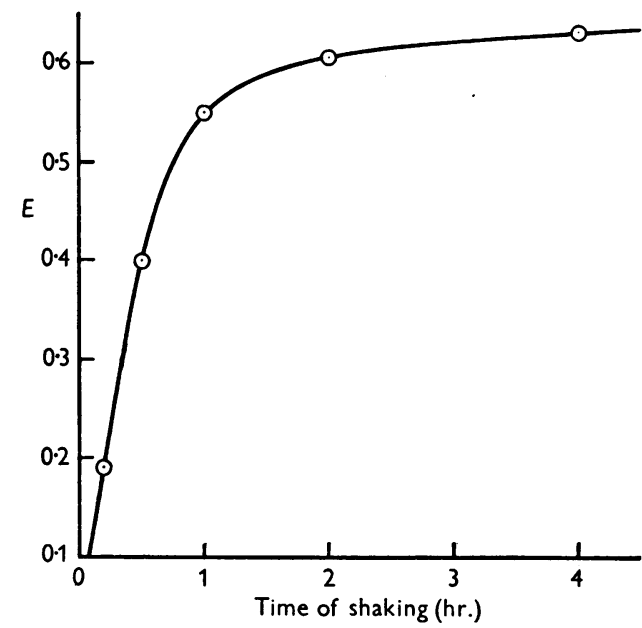

Fig. 2. Relationship between time of reaction and intensity of colour produced in coupling fluorodinitrobenzene and glycine.

$6 \mathrm{~N}-\mathrm{HCl}$. The $\mathrm{HCl}$ was removed in a vacuum desiccator over $\mathrm{KOH}$ and $\mathrm{P}_{2} \mathrm{O}_{5}$ and the residue diluted to $2 \mathrm{ml}$. with water. Samples $(0.5 \mathrm{ml}$.) were transferred to $15 \mathrm{ml}$. test tubes and shaken for $4 \mathrm{hr}$. with a mixture of FDNB (0.05 g.), methanol $\left(0.5 \mathrm{ml}\right.$.) and $\mathrm{NaHCO}_{3}$ (about $50 \mathrm{mg}$.). At the end of this time the mixture was diluted with water $(2 \mathrm{ml}$.) and the extraction procedure described in the previous section followed. The mixed DNP-amino-acids were then transferred in solvent CB to a Celite column. This solvent-buffer system allows ready separation of DNP-glycine. There is a fast yellow band containing the DNP-derivatives of the aromatic amino-acids, lysine, proline, and the higher homologues of glycine; this is followed by a clearly separated glycine band $(R=0.29)$ and a residual band of serine, threonine and the acidic amino-acids remains on the column. The glycine band was collected and estimated as indicated under Procedure. Three successive samples of hydrolysed albumin gave the following results expressed as 'Spekker' drum readings: $0.36,0.37,0.36$ (equivalent to $4.55 \mathrm{~g}$. glycine/100 g. albumin).

\section{REFERENCES}

Callow, R. K. \& Work, T. S. (1952). Biochem. J. 51, 558.

Howard, G. A.\& Martin, A. J. P.(1950). Biochem. J. 46, 532. Moore, S. \& Stein, W. H. (1949). J. biol. Chem. 178, 53.
Moore, S. \& Stein, W. H. (1951). J. biol. Chem. 192, 663. Perrone, J. C. (1951). Nature, Lond., 167, 513.

Sanger, F. (1945). Biochem. J. 39, 507.

Stein, W. H. \& Moore, S. (1948). J. biol. Chem. 176, 337. 